\section{Die heel mooiste Afrikaanse liefdesgedigte.}

Fanie Olivier (samesteller). Kaapstad: Human \& Rousseau, 2016. 320 pp. ISBN: 9780798170406.

DOI: http://dx.doi.org/10.17159/tvl.v.54i1.22

Die vyfde uitgebreide weergawe van Die heel mooiste Afrikaanse liefdesgedigte (2016), wat saamgestel is deur Fanie Olivier, verskyn vyf jaar ná die vorige uitgawe. Die eerste uitgawe van Die mooiste Afrikaanse liefdesgedigte het in 1986 verskyn, die tweede in 1992, die derde in 2001, en die vierde in 2010. Let op die veranderde titel van die mees resente uitgawe, wat nou $\mathrm{Die}$ heel mooiste Afrikaanse liefdesgedigte heet.

Die samesteller stel die probleem van die seleksie van gedigte soos volg as 'n retoriese vraag in die voorwoord tot die bloemlesing: "Hoe verwoord jy ooit jou keuse en hoe verdedig jy jou teen diegene (digters en lesers) wat ongelukkig voel oor gedigte wat weggelaat is?" Die antwoord hierop is nie voor die hand liggend nie, maar ' $n$ deegliker verantwoording sou verhelderend gewees het. Joan Hambidge argumenteer in haar resensie dat so ' $n$ verantwoording onder andere studente sal help om die literêre tradisie beter te verstaan, dat daar oor die belang van versvorme uitgewei kan word, en 'n aanduiding gegee kan word van intertekstuele skakels.

Die waarde van die bundel is dat dit ook as trekpleister kan dien vir diegene wat nie bekend is met die Afrikaanse poësie nie. Gunstelinge soos C. Louis Leipoldt se "Wys my die plek waar ons saam gestaan het" (25) en Breyten
Breytenbach se "Allerliefste, ek stuur vir jou'n rooiborsduif" (agterblad), is gedigte wat aan die meeste lesers in Afrikaans bekend is, maar die reikwydte van die bloemlesing is van so 'n aard dat dit ' $n$ groot aantal liefdesgedigte van heelwat digters in die Afrikaanse poësie aan die lesers bekend sal stel.

'n Ander groot bate van die bloemlesing is dat dit die evolusie van Afrikaanse liefdesgedigte oor meer as 'n eeu aandui. Die eerste gedig in die bloemlesing is van Pulvermacher, getiteld "Dopper Joris en sy seiltje" en dateer uit 1873. Nuwe digters word ook dan in die bloemlesing opgeneem en nuwe werk van reeds bekende digters word opnuut aan die leserspubliek bekend gestel. Interessant genoeg is die gedigte wat gekies is uit die tydperk 1873-2009 steeds dieselfde; daar is dus slegs nuwe gedigte wat sedert 2010 gepubliseer is, bygevoeg. Die vraag ontstaan wel of dit dan die moeite werd is vir diegene wat die vorige bloemlesing gekoop het om die nuwe weergawe aan te skaf? Die eerste van die nuwe gedigte verskyn in 2010 en is "paspoort" van T. T. Cloete:

paspoort

ek krap in jou nalatenskap rond

'n sakdoek met'n afdruk van jou mond jou kredietkaart

(die laaste trekking 3 Maart toe het jy by Gert se salon jou hare laat doen tot die dood toe was jy gesteld

op mooi lyk) 
het ek oorgehou na jare

en ja jou paspoort wat nog altyd geld...

In die bostaande gedig van Cloete word een van die temas van die liefde wat in die bundel aangespreek word, naamlik die verlies van 'n geliefde, geopper. Fanie Olivier se gedig "tussenteks" (242-3) uit Apostroof (2010) sluit by die tema van die verlies van 'n geliefde aan. Die liefde neem egter ' $n$ duisend vorme aan en die versamelwerk is sprekend van die velerlei stemme wat die liefde op verskillende maniere besing. Ander temas sluit in verlies soos in Martina Klopper se "Skedonk 1" (240) verwoord word, die besinning erotiese liefde soos Andries Samuel se gedig "jy is nog nie kaal voor my nie" (247-8), herinneringe aan geliefdes soos onder andere in Johann de Lange se gedig "Alleenspraak by donkermaan" (250-1) voorkom.

Die Afrikaanse letterkunde het 'n goeie aantal liefdesgedigte die afgelope vyf jaar ryker geword. Bydrae soos Marlene van Niekerk se "By die donker wrong van sterre" (264) uit haar bekroonde bundel Kaar (2013) en Andries Bezuidenhout se treffende gedig "koelkas" (264) in Veelvuldige gebruike vir huishoudelike toestelle (2014) sou as voorbeelde hiervan kon dien. Vergelyk die gedig van Bezuidenhout:

\section{Koelkas}

volgens die tweede wet van termodinamika

is verkoeling die meganika van hitte verwyder, eerder as koue byvoeg:

ook bekend as kriogenie.

koue, my lief, is dus niks anders as die afwesigheid van hitte nie

en ek wat op die klipvloer bewe vandat jy nie meer hier is nie.

Gedigte uit nie minder nie as twaalf resente debuutbundels is by die versamelwerk ingesluit, en sluit onder andere gedigte van Fourie Botha se Donkerkamer (2011), Karen Kuhn se Ingeboek (2012) en Nathan Trantaal se Chokers en survivors (2013) in. Dit is dan ook interessant om te sien dat die bekende lirieke van die lied "Vir jou" (251) deur Coenie de Villiers by die bloemlesing ingesluit is, wat vra na die raakvlak tussen vers en liriek. Ook is die waarde van die bundel daarin geleë dat die nuwe werk van baie bekende digters in Afrikaans wat steeds nuwe bundels publiseer soos Breyten Breytenbach, Daniel Hugo, Petra Müller, Johann de Lange, Joan Hambidge en Antjie Krog daarin opgeneem word. Hiervolgens kom 'n mens iets te wete van die wyse waarop die digter die liefde deur die jare beskryf.

Die heel mooiste Afrikaanse liefdesgedigte bied toegang tot 'n wye versameling liefdesgedigte in Afrikaans en strek oor meer as 'n eeu. Die bloemlesing sal veral nuttig wees vir die beginnerleser of student om hom of haar met van die mooiste gedigte wat Afrikaans bied in kontak te bring, maar die bloemlesing gee ook insig in die mees resente werk van Afrikaanse digters en sou as barometer 
kon dien van wat tans in die Afrikaanse poësie aan die gebeur is.

\section{Geraadpleegde bron}

Hambidge, Joan. "Die heel mooiste Afrikaanse liefdesgedigte." Woorde wat weeg. 16 Feb. 2016. 1 Des. 2016. <http://joanhambidge.blogspot. co.za/2016/02/fanie-olivier-samest-die-heelmooiste.html>.

\section{Alwyn Roux}

erouxap@unisa.ac.za

Universiteit van Suid-Afrika

Pretoria 